\title{
SOCIAL SECURITY OF UKRAINE AND THE EU: ASPECTS OF CONVERGENCE AND IMPROVEMENT OF MIGRATION POLICY
}

\author{
Taras Vasyltsiv' ${ }^{1}$, Ruslan Lupak², Marta Kunytska-Iliash ${ }^{3}$
}

\begin{abstract}
Unresolved problems of social and economic development of Ukraine, exacerbated by critical negative consequences of military aggression and political instability, are accompanied by deep socio-economic contradictions and aggravation of large-scale social problems. At the same time, the qualitative system of social security, characteristic of the EU, is not formed. As a result, negative phenomena and trends are accumulated in social sphere there that manifest themselves in the critical deformations of social development, with the formation of threats of degradation and depopulation, the increase of environmental problems, deterioration of social structure, weakening of social guarantees of human rights that are evidenced and confirmed by mass and active labour migration of the Ukrainians abroad. Ensuring Ukraine's social security objectively requires an in-depth study based on a systematic approach, applying EU principles, provisions, practices, and standards. The purpose is to substantiate approaches and means of convergence of social security of Ukraine and the EU and develop recommendations for the improvement of migration policy. Methodology. As the methodological basis of the study, theories of socio-economic growth, modern concepts of institutional and structural economic reforms have been worked out, methods of statistical, structural-functional, and system analysis, grouping have been applied. Results. The imbalances of social security of Ukraine and the EU have been determined according to the following components: labour market and employment of population; reproduction of population and labour potential of the state; migration and food security. Areas of accelerated asymmetry increase in the social development of Ukraine and the EU, which serve as a key factor in "pushing out" the population and high rates of labour migration from Ukraine to the EU Member States, have been identified. Strategic approaches and means of equalizing critical deformations and convergence of the system of social security of Ukraine in the process of integration into the EU have been determined; tools for improving the state migration policy have been developed, which implementation would result in improvement of the systemic and structural characteristics of labour potential migration. Conclusion. The study results obtained represent the existence of significant disparities in key indicators and components of the social security system of Ukraine and the EU. Low level of living standards and social protection of population serves as a factor in increasing the scope of external labour migration and, correspondingly, a critical weakening of human and labour potential of the state. Tools and means of the state policy of convergence of the social security system of Ukraine and the EU should focus on achieving the goal of systemic development of human capital and be implemented in the following directions: ensuring demographic security, upgrading health care system, renovating the quality of education, preserving cultural values, establishing a competitive labour market, improving housing affordability, social infrastructure development, systemic social insurance of population.
\end{abstract}

Key words: social security, convergence of the social policy of Ukraine and the EU, human potential, migration.

JEL Classification: E24, F22, H53, J63

\footnotetext{
Corresponding author:

${ }^{1}$ State Institution "Institute of Regional Research named after M.I. Dolishniy

of National Academy of Sciences of Ukraine", Ukraine.

E-mail: tgvas77@ukr.net

ORCID: https://orcid.org/0000-0002-2889-6924

${ }^{2}$ Lviv University of Trade and Economics, Ukraine.

E-mail: economist5555@ukr.net

ORCID: https://orcid.org/0000-0002-1830-1800

${ }^{3}$ Stepan Gzhytskyi National University of Veterinary Medicine and Biotechnologies Lviv, Ukraine.

E-mail: kunytskam@gmail.com

ORCID: https://orcid.org/0000-0003-2559-1065
} 


\section{Introduction}

Ukraine is characterized by the lower key indicators of human development in comparison with the majority of EU countries, which objectively hinder the European integration and Euro-Atlantic aspirations of Ukraine, and reflect real problems in the field of formation and effective use of human capital. Both the cause and the consequence of these trends are the lack of quality and complete system of social security of the state. The imbalances of social security between Ukraine and the EU are a powerful factor of "pushing" Ukrainians out of Ukraine and their active foreign, primarily labour migration.

The unevenness of the social security systems of Ukraine and the EU not only leads to weakening of the national security of Ukraine (primarily due to the deterioration of the intellectual and labour capital of the nation, the restriction of resource supply, and the reduction of the competitiveness of the economy, decrease of the social and investment attractiveness of the territories) but also threatens Europe as a whole due to aggravation of poverty on the continent, insufficiently regulated migration, declining incomes, under-utilization of the potential employment and consumption in the domestic market of one of the largest European countries.

Research of such scholars as C. Ziller, M. Wright and M. Hewstone (2018), Y. Young, P. Loebach and K. Korinek (2018), S. Lee (2018), J.-E. Bettignies and D. Robinson (2018), C. Jennings and S. SanchezPages (2017), C. Brinch, E. Hernæs and Z. Jia (2017), O. Vlasyuk (2016), B. Bratsberg, R. Oddbjørn and K. Röed (2014), F. Gonzalez and J.-F. Wen (2014), V. Gorbulin and A. Kaczynski (2010), M. GonzalezEiras (2008), R. Burkhauser and K. Holden (1982) is devoted to the problems of ensuring the country's social security, including the migration factor.

Key aspects of the formation and expansion of the European principles and standards for the provision, functioning, and development of the economy in the context of strengthening the formation of the system of social security of the state are highlighted in works of such scholars as G. Genna, F. Justwan (2019), L. D’Hooge, P. Achterberg and T. Reescens (2018), O. Ilyash (2018), E. Shcherbakova (2018), J. Paju (2017), K. Bagmet and H. Obeid (2017), P. Schoukens (2016).

The results of research of S. Pozo (2018), A. Young and M. Tackett (2018), F. Mandelman (2016), C. Naiditch, A. Tomini and C. Lakhdar (2015), B. Chiswick and P. Miller (2014), K. Han (2013), M. Fisher (2013), P. Klein and G. Ventura (2009), C. Mueller (1982) are a significant theoretical and applied basis for the formation of the principles of social security of the state, improvement of migration policy.

Despite tried and tested theoretical and methodological principles of the state policy of the formation of a system of social security, the issue of not so much the formation and provision, as the achievement of convergence of the key conditions and parameters of social security systems of the states implementing the processes of the European integration, and the EU, as well as identification of the most systemic negative consequences of existing social security imbalances (in particular, critically threatening scope of external labour migration) and the development of tools and means of counter-strategy in the process of harmonization of social security systems, simultaneously implying a strong synergy effect, remains a significant layer of outstanding theoretical aspects and practical recommendations.

The purpose of the article is to substantiate approaches and means of social security of Ukraine and the EU convergence and to develop recommendations for the improvement of migration policy.

\section{Comparison of social security options of Ukraine and the EU: confirmation of threats growth}

Comparative characteristics of the key indicators of social security of Ukraine and the EU testify to the existence and expansion of critically threatening social security challenges. Thus, in Ukraine, the income level of the population is significantly lower, and there are problems in the main parameters of the labour market (Table 1).

The level of average monthly income per one household member in 2017 was EUR 96, while the average value of this indicator in EU countries was EUR 1702, being 17.7 times higher. In particular, the highest figures among European households were in Luxembourg (EUR 2618), Germany (2318), Austria (2222), France (2077), and the lowest ones were in Bulgaria (920), Latvia (1120), Greece (1211).

It should be noted that in early 2018, the minimum monthly wages in the EU countries ranged from EUR 261 (in Bulgaria) to EUR 1999 (in Luxembourg). At the same time, all European countries can be divided into three groups: the first one includes the countries where minimum monthly wages are less than EUR 500 (Bulgaria (261), Lithuania (400), Romania (408), Latvia (430), Hungary (445), Croatia (462), Czech Republic (478) and Slovakia (480)); the second one comprises the countries where minimum monthly wages range from EUR 500 to EUR 1000 (Estonia (500), Poland (503), Portugal (677), Greece (684), Malta (748), Slovenia (843) and Spain (859)); the third one includes the countries with the minimum monthly wages exceeding EUR 1000 (Great Britain (1401), Germany (1498), France (1498), Belgium (1563), the Netherlands (1578), Ireland (1614), and Luxembourg (1999) (Public Union "Economic Discussion Club", 2019; Eurostat, 2018). As far as Ukraine is concerned, the minimum monthly wages in equivalent to euros 
Table 1

Social security of Ukraine and the EU in 2017: labour market and employment parameters

\begin{tabular}{|c|c|c|c|c|c|c|c|c|c|}
\hline \multicolumn{2}{|c|}{ Indices } & 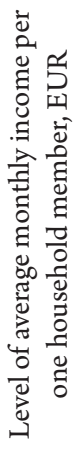 & 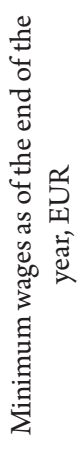 & 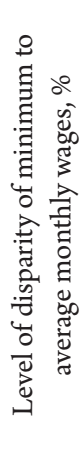 & 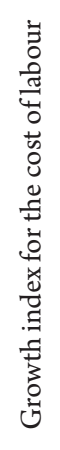 & 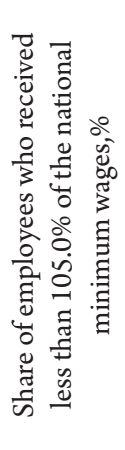 & 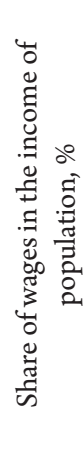 & 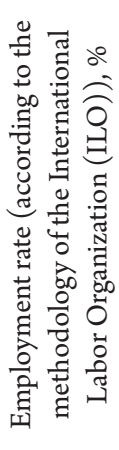 & 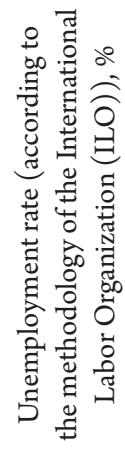 \\
\hline \multicolumn{2}{|r|}{ Ukraine } & 96 & 108 & 48.0 & 5.5 & 3.0 & 61.0 & 64.2 & 10.1 \\
\hline \multirow{3}{*}{$\begin{array}{l}\stackrel{\infty}{\Lambda} \\
\stackrel{\rho}{\rho}\end{array}$} & average across the countries & 1702 & 856 & 53.0 & 2.1 & 5.0 & 76.0 & 71.1 & 8.3 \\
\hline & maximum value & 2618 & 1999 & 64.0 & 15.1 & 19.0 & 91.4 & 81.2 & 25.9 \\
\hline & minimum value & 920 & 261 & 39.0 & 0.2 & 0.0 & 66.8 & 63.9 & 4.1 \\
\hline
\end{tabular}

Source: compiled according to (Public Union "Economic Discussion Club", 2019; State Statistics Service of Ukraine, 2019; Eurostat, 2018)

amounted to EUR 108, which is almost 2.5 times less than its lowest value among EU countries.

If the share of minimum wages in the average earnings in the EU countries ranges from 39.0\% (in Estonia, Ireland) to $64.0 \%$ (in Portugal, Slovenia), then in Ukraine the corresponding ratio is $48.0 \%$. As a result, both the level of income and the minimum wages in Ukraine are significantly inferior to the lowest value of these indicators across all EU countries.

As of $2017,64.2 \%$ of the population were employed in Ukraine, while in the EU percentage of employment averaged $71.1 \%$ (6.9 p.p. more), and the maximum value was $81.2 \%$ (17.0 p.p. more). As for the EU countries, the highest employment rates were recorded in Sweden (81.2\%), Germany (78.7), United Kingdom (77.6), Denmark (77.4), and the lowest rate was in Greece (56.2), Croatia (61.4), Italy (61.6).

Ukraine yielded on the unemployment rate (and this is official data, while actual data are much worse), as well as on the share of wages in the income of the population. In particular, for the last decade, the unemployment rate in the 28 member countries of the $\mathrm{EU}$ is the lowest one $(8.3 \%)$. Among the Member States, the lowest unemployment rate was observed in the Czech Republic (2.4\%), Germany and Malta (3.5\%), Hungary (3.7\%), and the highest unemployment rates were observed in Greece $(20.8 \%)$ and Spain (16.1\%).

As it follows from the data presented in Table 2, Ukraine is characterized by a lower level of population reproduction and labour potential. Thus, the birth rate in Ukraine was $0.5 \mathrm{ppm}$ lower than the average for the EU countries, and the death rate was 4.2 ppm higher; the birth rate dropped by 0.2 per one woman in the reproductive age.

Among the 28 member countries of the EU, the death rate exceeds the birth rate in 16 , in particular, the highest difference was observed in Bulgaria (6.5 p.p.), Latvia and Lithuania (4.1), Croatia (4.0), Hungary (3.8), Romania (3.6). And, on the contrary, the birth rate exceeded the death rate in Ireland (by 6.6 p.p.), Cyprus (3.7), Luxembourg (3.3), and Sweden (2.4).

At the same time, the highest birth rates are in Sweden and France (fertility rate per woman in the reproductive age - 1.9), the lowest ones are in Spain and Italy (1.3). If the mean age of childbearing in the population is 28.0 years in Ukraine, then in the EU it is 2.6 years more

Table 2

Social security of Ukraine and the EU in 2017: population reproduction and labour potential parameters

\begin{tabular}{|c|c|c|c|c|c|c|c|c|}
\hline \multicolumn{2}{|c|}{ Indices } & 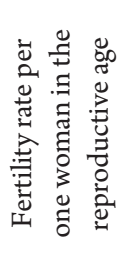 & 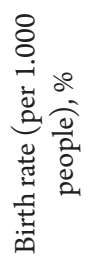 & 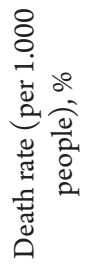 & 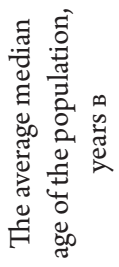 & 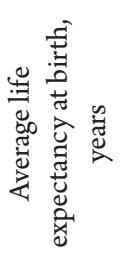 & 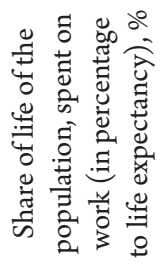 & 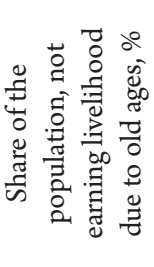 \\
\hline \multicolumn{2}{|r|}{ Ukraine } & 1.4 & 9.4 & 14.5 & 40.8 & 71.9 & 48.8 & 37.8 \\
\hline \multirow{3}{*}{ 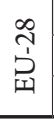 } & average across the countries & 1.6 & 9.9 & 10.3 & 42.6 & 80.9 & 44.0 & 29.9 \\
\hline & maximum value & 1.9 & 12.9 & 15.5 & 45.8 & 83.5 & 50.2 & 34.8 \\
\hline & minimum value & 1.3 & 7.6 & 6.3 & 36.6 & 74.9 & 37.7 & 20.5 \\
\hline
\end{tabular}

Source: compiled according to (Public Union "Economic Discussion Club", 2019; State Statistics Service of Ukraine, 2019; Eurostat, 2018) 
(30.6 years). Thus, among the European countries, the highest average age of mothers at maternity is in Ireland (32.1 years), Spain (32.0), Italy (31.8), Luxembourg (31.7), and the lowest average age is in Bulgaria (27.6), Romania (27.8).

It should be noted that if on the average across the EU countries, in 2017 the average life expectancy was 80.9 years (ranging from 74.9 years in Lithuania, Latvia and Bulgaria to 83.5 years in Spain), then in Ukraine it makes up only 71.9 years, or 9.0 years less. At the same time, both in Ukraine and in the EU, the average age of the population is quite mature: the median age of Ukrainians is 40.8 years, while the age of the EU population was 42.6 years. In this case, the youngest European country according to the median age of the population is Ireland (36.6 years), the oldest is Germany (45.8 years).

The indicators of the share of population, not earning livelihood, are significantly worse in Ukraine (37.8\%, while the average in the EU countries - 29.9\% (from $20.7 \%$ in Ireland to $34.8 \%$ in Italy), as well as share of life of the population spent on work ( $48.8 \%$ vs. $44.0 \%)$. In particular, the Italians and Luxembourgers are spending the least shares of their lives: $37.7 \%$ and $39.9 \%$ respectively, and the most shares of their lives spend Swedes (50.2\%), Danes (49.9), and the Netherlanders (49.0).

According to the information, presented in Table 3 , it is possible to give preliminary findings about the significantly lower rates of immigration and emigration of the population in Ukraine compared to the countries of Europe. However, the real state of affairs is not the same. Ukraine is the European leader in the scope of external labour migration. However, this refers to unreported labour migration. According to the National Bank of Ukraine, the amounts of remittances of the Ukrainian migrant workers in 2018 exceed 9.0 billion EUR, which is $18.3 \%$ more than in 2017; the amounts of remittances exceed the amounts of direct foreign investments in Ukraine by 3.8 times (National Bank of Ukraine, 2019).

According to various estimates, about 3.0-5.0 million Ukrainians participate in external labour migration, ranging from $12.0 \%$ to $20.0 \%$ of the able-bodied population of the state. This is an evident proof of not only critically high scopes of external labour migration but also of the rapid growth of its rates and the increasing threats to Ukraine's economic and social security.

It should be noted that in 2017, net migration is characteristic of the 23 EU countries, where this indicator varied from $0.1 \mathrm{ppm}$ (in Poland) to $31.3 \mathrm{ppm}$ (in Luxembourg). Instead, in other countries, there was a migration decline, which varied from $-0.8 \mathrm{ppm}$ (in Bulgaria) to $-9.7 \mathrm{ppm}$ (in Lithuania). Most of the net migration fell on Germany (476.000 people), Great Britain (281.000), Spain (166.000), and Sweden (102.000). At the same time, a particularly significant negative balance of migration was formed in countries with a long-term prevailing migratory drop-off, including: Romania (-49.600), Croatia (-31.800), Lithuania (-27.600) (Shcherbakova, 2018; Eurostat, 2018).

Both the consequence and the cause of insufficient social security in Ukraine were the values of indicators of the food component of the social security system (Table 4). Thus, average daily dietary calories in Ukraine in 2017 amounted to $2,742 \mathrm{kcal}$, while the average calories in the EU were $3416 \mathrm{kcal}$ ( $24.6 \%$ more). Among the European countries, the lowest dietary calories are consumed by Cypriots (2661 kcal/day), Bulgarians (2877), Slovaks (2902), Hungarians (2988), and the highest calorie diet (over $3,500 \mathrm{kcal}$ a day) is consumed by the Belgians (3793), Austrians (3784), Irish (3591), Luxembourgers (3568), Italians (3539). In general, the disparity between Ukraine and the highest level of this indicator made up 38.3\%. However, as we see, the value of this indicator in Ukraine is inferior even to the minimum level in the EU countries. This is evidence of inadequate consumption of the necessary products by the population and, therefore, the complication of opportunities for proper reproduction.

The population of the EU countries has better financial capacities, which is reflected in the spending pattern. So, if in Ukraine food expenditures account for $54.3 \%$ of total consumer's expenditures, then average food expenditures in the EU countries make up only $12.3 \%$. Even in the European countries with a maximum value of this indicator, the level of food expenditures is significantly lower, by 34.8 p.p. It should be noted that the lowest levels of consumer's expenditures on food of less than $10.0 \%$ in the EU countries were found in the households of Luxembourg, Austria, and Ireland, and the highest - in Lithuania, Estonia, and Bulgaria (about 20.0\%).

Table 3

Social security of Ukraine and the EU in 2017: migration policy parameters

\begin{tabular}{|c|c|c|c|c|c|}
\hline \multicolumn{2}{|c|}{ Countries } & $\begin{array}{l}\text { Inter-State immigration } \\
\text { of the population } \\
\text { intensity ratio, per } 1.000 \\
\text { people }\end{array}$ & $\begin{array}{l}\text { Inter-State emigration of } \\
\text { the population intensity } \\
\text { ratio, per } 1.000 \text { people }\end{array}$ & $\begin{array}{l}\text { Inter-State migration } \\
\text { transfers of the } \\
\text { population intensity } \\
\text { ratio, per } 1.000 \text { people }\end{array}$ & $\begin{array}{l}\text { Net (gross) migration } \\
\text { rate of the population, } \\
\text { per } 1.000 \text { people }\end{array}$ \\
\hline \multicolumn{2}{|r|}{ Ukraine } & 14.0 & 7.0 & 11.0 & 0.5 \\
\hline \multirow{3}{*}{ 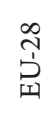 } & average across the countries & 8.8 & 18.1 & 15.3 & 2.4 \\
\hline & maximum value & 47.2 & 52.1 & 69.0 & 31.0 \\
\hline & minimum value & 5.0 & 3.2 & 2.0 & -10.0 \\
\hline
\end{tabular}

Source: compiled according to (Public Union "Economic Discussion Club", 2019; State Statistics Service of Ukraine, 2019; Eurostat, 2018) 
Table 4

Social security of Ukraine and the EU in 2017: food supply parameters

\begin{tabular}{|c|c|c|c|c|c|c|c|c|}
\hline \multicolumn{2}{|c|}{ Countries } & 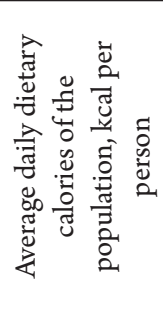 & 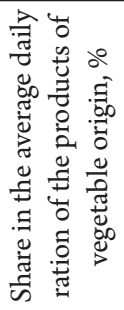 & 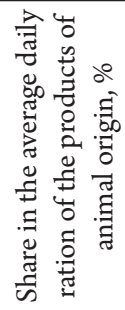 & 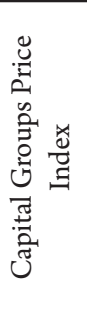 & 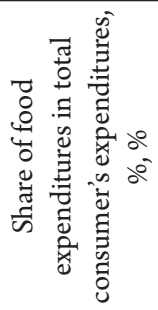 & 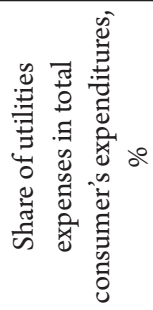 & 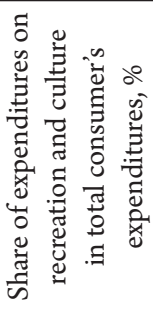 \\
\hline \multicolumn{2}{|r|}{ Ukraine } & 2742 & 71 & 29 & 17.9 & 54.3 & 17.2 & 1.5 \\
\hline \multirow{3}{*}{ 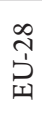 } & average across the countries & 3416 & 71 & 29 & 2.1 & 12.3 & 22.5 & 8.5 \\
\hline & maximum value & 3793 & 78 & 22 & 6.0 & 19.5 & 29.1 & 11.0 \\
\hline & minimum value & 2877 & 61 & 39 & -1.9 & 8.1 & 10.4 & 4.5 \\
\hline
\end{tabular}

Source: compiled according to (Public Union "Economic Discussion Club", 2019; State Statistics Service of Ukraine, 2019; Eurostat, 2018)

Similar tendencies are specific also to comparative opportunities of Europeans and Ukrainians concerning expenditures on recreation and culture. If in Ukraine the share of expenditures on this source was only $1.5 \%$, then the average in the EU countries amounted to $8.5 \%$, and in the countries-leaders on this indicator they spend more than $10.0 \%$ (Finland (11.0\%), Denmark (10.9\%), Malta (10.8\%), Slovakia (10.6\%).

The population of Ukraine is also in a permanent state of shock associated with high rates of inflation and instability of the national currency. Thus, just in 2017, the Capital Groups Price Index reached $17.9 \%$, while in the EU countries it averaged $2.1 \%$.

At the same time, it should be noted that the expenditure level of the EU citizens for payment of utility bills is higher, 22.5\% (Estonia (29.1\%), Great Britain (28.4\%), Cyprus (26.5\%), Germany (25.6\%), Belgium and the Czech Republic (24.5\%), Ireland (23.9\%), whereas in Ukraine it reaches $17.2 \%$. But this situation should not be regarded as positive, as there is a continuous increase in utilities cost, and a significant part of the population of Ukraine is on the verge of poverty and cannot fully pay for the housing and communal services received.

Despite the problems described, a gradual increase since 1997 in the level of human development index is peculiar for Ukraine, which is positive.

But, despite the upward dynamics of this index, Ukraine's places in the country's human development ranking remain low. For example, in 2017 Ukraine was at the $88^{\text {th }}$ place out of 189 countries of the world. By 2016 there it lost four rating positions. If in 1990-1994 Ukraine was at the $45^{\text {th }}$ place in the ranking, then during 1995-2017, the highest value, the $69^{\text {th }}$ place was achieved in 2010. Further, the overall trend is negative, which, on the one hand, is the evidence of deterioration of social security system functioning in Ukraine and, on the other hand, the consequence of the shortcomings of the state policy of ensuring social security (Human Development Reports, 2018).
The policy of convergence of the social security system of Ukraine and the EU, the main objective of which is to resist socio-economic risks that reduce the level of convergence of the social security system of Ukraine and the EU in the process of European integration, requires an increase in the indirect effects of collaboration in the social sphere.

\section{Low social security causes migration from Ukraine to the EU}

Low level of convergence of reforms and transformations in the sphere of social security of Ukraine and the EU is due to the passivity and financial insolvency of the existing state policy, an overabundance of goals and a small number of means to achieve them, in particular:

- lack of real opportunities for reforming the labour market reproduction policy and employment regulation; - limited influence of the state policy on raising the level of real earnings of population and reforming the system of social protection of wage workers and labour migrants;

- lack of effective social dialogue and cooperation by EU Partner Countries;

- deepening of regional disproportions in the development of social infrastructure and lack of procedures for implementing EU norms and practices for the development of the primary healthcare sector; - inconsistency of educational potential with the needs of innovative development of the region's economy; - the increase of gender violence, discrimination against women and men in the labour market and their weak social protection in society.

Over the last years, an accelerated increase in asymmetry in the development of the social security system of Ukraine and the EU has been observed, being one of the main reasons for the intensification of migration (in particular, external migration) processes in Ukraine (Figure 1).

It should be noted that today Ukraine is among the top ten donor countries of the international labour migrants 


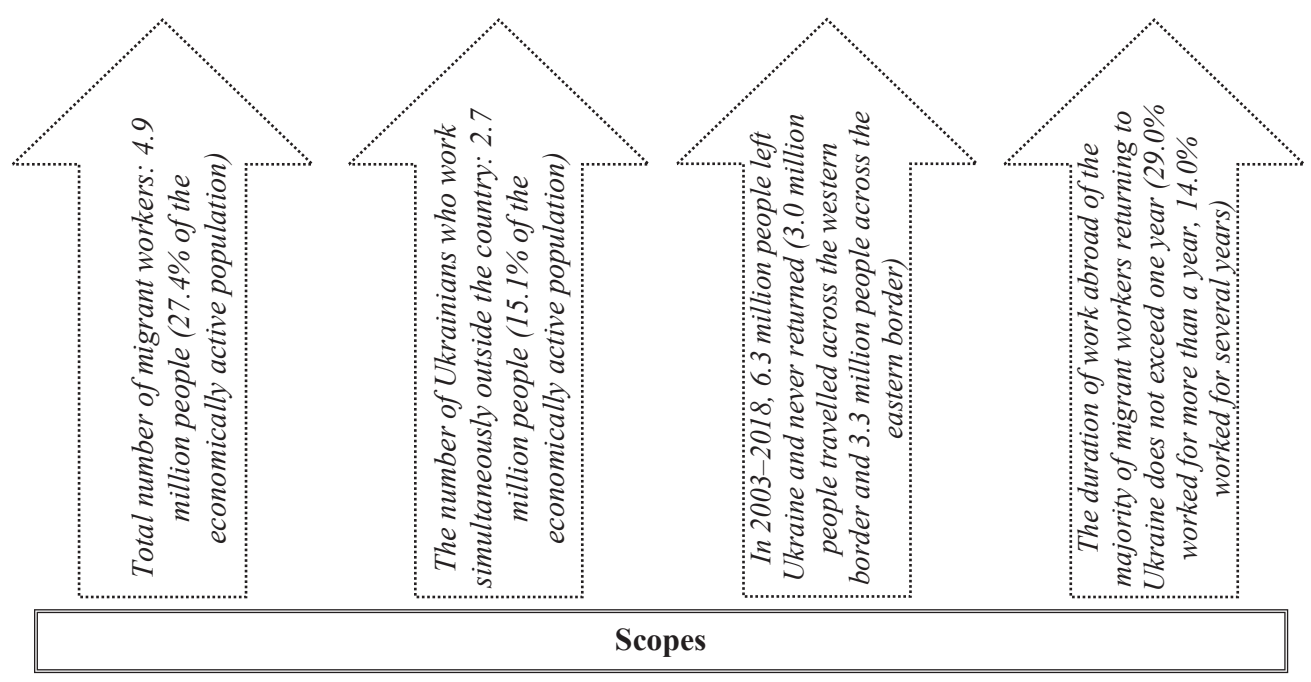

Figure. 1. Key quantitative indices of external labour migration of Ukraine intensity as of the beginning of 2019

Source: Centre for Economic Strategy, 2019

in the world. Thus, according to various estimates, almost $28.0 \%$ of the economically active population of Ukraine are external labour migrants while, at the same time, more than $15.0 \%$ of the able-bodied population may be outside the country.

\section{Alternatives to social security modelling}

An important role in the process of formation and implementation of the state policy of strengthening
Ukraine's social security should be assigned to the synthesis of both positive practices and failures as a part of the world experience of state regulation in this area, which is especially important in the context of taking into account possible risks and threats to the state's social security in a short-, medium-, and long-term prospects. It is appropriate to take into account the positive practices of European states in implementing liberal, conservative, and paternalistic models of social policy (Table 5).

Table 5

Characteristics of social policy models in the EU countries

\begin{tabular}{|c|c|c|}
\hline Models & Features & States \\
\hline Liberal & $\begin{array}{l}\text { - restriction of state regulation of the system of social and labour relations; } \\
\text { - ensuring reliable legal protection of non-governmental organizations in the social sphere; } \\
\text { - achievement of the high efficiency of trade union organizations in the field of social protection; } \\
\text { - providing targeted social assistance to the poorest people; } \\
\text { - enhancement of the involvement of the insurance industry in financing social programs; } \\
\text { - restriction of budget financing of social services }\end{array}$ & $\begin{array}{c}\text { United Kingdom } \\
\text { of Great Britain, } \\
\text { Ireland }\end{array}$ \\
\hline Conservative & $\begin{array}{l}\text { - approval of the state control system of compulsory collective responsibility; } \\
\text { - developed corporate social security system; } \\
\text { - expansion of social partnership as an arrangement for coordinating the interests of employees and } \\
\text { employers; } \\
\text { - approval of consistency between the insurance contributions of employees and employers and the } \\
\text { amount of budget deductions for social measures; } \\
\text { - providing by the state of high control over channels of redistribution of budgetary social deductions; } \\
\text { - distribution of practice of paying the amount of social assistance proportional to the received earnings } \\
\text { and the amounts of insurance payments }\end{array}$ & $\begin{array}{c}\text { Sweden, } \\
\text { Denmark, } \\
\text { Finland, Norway }\end{array}$ \\
\hline Paternalist & $\begin{array}{l}\text { - increased participation in the regulation of social and labour relations of state and departmental } \\
\text { structures; } \\
\text { - the versatility of social protection as the right of all citizens guaranteed by the state; } \\
\text { - establishment of the high role of the state in the socialization of incomes of the population, where } \\
\text { public authorities provide a high level of quality and accessibility of social services; } \\
\text { - expansion of solidarity system of social protection; } \\
\text { - implementation of mechanisms for the functioning of insurance funds and warranty bonds; } \\
\text { - consolidation of legal provisions and motivation for concluding collective contracts and agreements }\end{array}$ & $\begin{array}{l}\text { Germany, } \\
\text { France, Austria, } \\
\text { Belgium, } \\
\text { the Netherlands, } \\
\text { Switzerland }\end{array}$ \\
\hline
\end{tabular}

Source: composed by the authors 


\section{Means of social security convergence}

European experience demonstrates that only an integrated approach to addressing the identified problems is effective by way of smoothing critical social security deformations. Taking into account the abovementioned critical risks in the social sphere that do not contribute to the convergence of the social security system of Ukraine and the EU, the strategic approaches and tools of intensifying the implementation of reforms in Ukraine and changes in the conditions of European integration should be as follows:

1) in order to ensure the improvement of human development environment, fight against discrimination, the creation of new competitive jobs, the growth of employment rates and control of the factors of "pushing out" the population abroad, strengthening the market flexibility and security of the employed workers, the implementation of European principles and guidelines of responsible business and corporate practices should be guaranteed. The provisions of the UN Global Compact 2000 and the ILO Tripartite Declaration on Corporate Social Responsibility are the institutional and methodological support of these practices;

2 ) in order to ensure growth of employment rates of the population and reduce the number of compulsory dismissal of workers, the Ministry of Social Policy of Ukraine and the National Employment Agency jointly with the Confederation of Free Trade Unions of Ukraine are to begin work on the introduction of a fourday working week for low-skilled workers (reduction of working hours by $20.0 \%$ ); in order to legalize the "shadow" employment and support the competitiveness of the economically active population in the labour market, urban and district employment centres should introduce the practice of holding European forums and consultations; a package of laws on financial and banking activities in order to increase the stability and attractiveness of the formal employment sector should be adopted at the legislative level, and risk pooling bank (insurance bank) should be established for refinancing, reimbursement of interest rates for using the currency; 3 ) in order to intensify cooperation in creating the full potential for the population in ensuring an adequate level of working life quality, to improve the system of social protection within the framework of the implementation of the Association Agreement with the $\mathrm{EU}$, work for bringing the legislative and normative base of Ukraine to the European practices and requirements should be continued. This requires clarification of a number of important provisions of the institutional and legal system in the areas of employment of disabled persons, alternative pensions, social insurance, etc.

4 ) in order to implement the intentions regarding the improvement of resource provision in the field of medicine and healthcare, Strategy for the Development of the National Blood System in
Ukraine should be put into practice. Opportunities for this will only appear after the formation of a multi-level system of relevant advisory committees under the leadership of the Independent Competent Authority (as prescribed by the Directive of the European Parliament and of the Council of Europe of 27 January 2003 No. 2002/98/EC);

5) the provisions of the International Health Regulations (IHR) for the purpose of prevention and better control of the spread of infectious diseases should be institutionalized; active cooperation with the member states of the IHR, in particular, with the means of institutional and technological cooperation, financial and resource assistance, creation of conditions and environment for the qualitative use of the advantages and opportunities of institutionalization of the IHR in the state should be carried out and developed;

6) the alignment (in accordance with European practices) of the institutional and psychological principles in the sphere of spatial mobility of young people, especially in the educational sphere, which will be facilitated by the formation of an appropriate electronic communication space (based on EURES model (European Job Mobility Portal) should be promoted within the framework of cooperation; various programs of student exchanges, joint foreign trainings, etc. should be implemented. It is necessary to promote such tools as "Youth Employment Initiatives" and "Youth Guarantee Schemes" within the framework of the Concept of the State Target Social Program "Youth of Ukraine" for 2016-2020.

Implementation of the said measures and initiatives will allow influencing virtually the most critical aspects of the social sphere, and at the same time involving the so-called points of prospective cooperation between Ukraine and the EU within the framework of social policy, which will have a dual effect in the context of convergence of social security systems.

\section{Means of migration processes regulating}

The overriding need in the context of the state control of migration processes is:

1) within the framework of the activity aimed at improving social protection of the Ukrainian migrant workers, to promote the implementation of contractual relations with the EU in the field of social protection and pension benefits of such persons, the formation of conditions and opportunities regarding the development and implementation of circular migration programs in both directions;

2 ) in order to reduce labour migration, to ensure increasing incomes of the population as a powerful factor in the control of external migration, and to implement high-quality alternative forms and methods of strengthening social responsibility of employers for the creation of appropriate working conditions 
and adequate social protection of employees. For the purposes of the latter, the practice of social dialogue has become widespread and effective in the EU countries; 3) to eliminate obstacles to the mobility of the population, to increase its territorial mobility, and also to ensure the growth of domestic demand for labour with the incentives of domestic employment of citizens as a tool of control of external labour migration. In order to provide the latter at the regional and local levels, it is necessary to promote the implementation of socioeconomic development programs, in particular, in support of the development of the most promising areas of economic activity for the respective territory;

4) for the proper adaptation of persons who are returning from abroad, it is important to develop a tool for receiving money by them until they are employed; to introduce a state system of tax and customs privileges and affordable financial and credit support for the launch of a private small business; to develop the mechanism of recognition of qualifications in accordance with their profession and specialization during employment abroad; to deepen European cooperation aimed at integrating labour migrants, in particular, implementation of the Action Plan on integration of refugees by 2020 .

Implementation of the measures specified will allow to improve the structural features of migration such as shadow/official, permanent/shuttle trader's, loss/ qualitative reproduction of human capital, low paid/ highly skilled labour, etc., which simultaneously will promote both the increase of the quality of life and improvement of the key characteristics of the system of social security of Ukraine, its actual approaching the standards of social security of the EU.

\section{Conclusions}

Social security challenges of Ukraine have intensified, especially in the areas of reproduction of the population and labour potential, functioning of social sphere and labour market, incomes and employment of the population. They result in worsening of working conditions and loss of material wealth, depopulation and aging of the nation, spread of poverty and wealth divide, deterioration of the material and technical, financial and investment, intellectual and personnel provision of healthcare, education, culture, art, sports, and as a consequence, in a decreased social protection of the population, increased mood of dissatisfaction with life and social policy of the government, including the desire for emigration and external labour migration.

Approximation of Ukrainian social security standards to the EU standards in the process of European integration, spatial and structural coherence and alignment of the elements of social security system are a prerequisite for modernization and formation of a more reliable system of social security of a person in Ukraine in accordance with the European approaches, principles, and provisions.

The state policy in the field of convergence of social security system of Ukraine and the EU, in particular, with regard to the regulation of migration processes, should be directed towards the achievement of the goal of systemic development of human capital, and be implemented in the following areas: ensuring demographic security, modernizing healthcare system, restoring the quality of education system, preserving cultural values, developing a competitive labour market, improving housing affordability, social infrastructure development, systemic social insurance for the population.

In the process of radical modernization of the social security system, state authorities should primarily focus on overcoming the negative impact of these challenges and threats, which determines the prospects for further studies. Delays in their overcoming complicate and postpone the result of full integration of Ukraine into the EU.

\section{References:}

Ziller, C., Wright, M., \& Hewstone, M. (2018). Immigration, social trust, and the moderating role of value contexts. Social Science Research, 10, 15-22.

Young, Y., Loebach, P., \& Korinek, K. (2018). Building walls or opening borders? Global immigration policy attitudes across economic, cultural and human security contexts. Social Science Research, 75, 83-95.

Lee, S. (2018). Social capital and health at the country level. The Social Science Journal, 55(1), 37-51.

Bettignies, J.-E., \& Robinson, D. (2018). When Is Social Responsibility Socially Desirable? Journal of Labor Economics, 36(4), 1023-1072.

Jennings, C., \& Sanchez-Pages, S. (2017). Social capital, conflict and welfare. Journal of Development Economics, 124, 157-167.

Brinch, C., Hernæs, E., \& Jia, Z. (2017). Salience and Social Security Benefits. Journal of Labor Economics, 35, $265-297$. Vlasyuk, O. S. (2016). System transformations of the national economy: challenges and expectations. Vol. 1. Bydgoszcz: University of Economy Publishing House.

Bratsberg, B., Oddbjørn, R., \& Røed, K. (2014). Immigrants, Labour Market Performance and Social Insurance. The Economic Journal, 124, 15-31.

Gonzalez, F., \& Wen, J.-F. (2014). A Theory of Top Income Taxation and Social Insurance. The Economic Journal, $125,1474-1500$. 
Gorbulin, V. P., \& Kaczynski, A. B. (2010). Stratehichne planuvannya: vyrishennya problem natsionalnoyi bezpeky [Strategic planning: meeting the challenges of national security]. Kyiv: National Institute for Strategic Studies. (in Ukrainian)

Gonzalez-Eiras, M. (2008). The future of social security. Journal of Monetary Economics, 55(2), 197-218.

Burkhauser, R., \& Holden, K. (1982). A Challenge to Social Security. Washington: Academic Press.

Genna, G., \& Justwan, F. (2019). Public perceptions of the European power hierarchy and support for a single European security and defense policy. The Social Science Journal, 2, 5-11.

D’Hooge, L., Achterberg, P., \& Reeskens, T. (2018). Imagining class: A study into material social class position, subjective identification, and voting behavior across Europe. Social Science Research, 70, 71-89.

Ilyash, O. (2018). European Aspirations of Ukraine in the Context of the Socio-Economic Security Risks Assessment: 2010-2018. Warsaw: Wydawnictwo Naukowe Uniwersytetu Mikolaja Kopernika.

Shcherbakova, E. M. (2018). Pervyye demograficheskiye itogi 2017 goda v YES [The first demographic results of 2017 in the EU]. Demoscope Weekly, 785-786. Retrieved from: http://demoscope.ru/weekly/2018/0785/ barom01.php (in Russian)

Paju, J. (2017). The European Union and Social Security Law. Oxford: Hart Publishing.

Bagmet, K., \& Obeid, H. (2017). Financing social protection in Ukraine and the European Union: current situation and prospects. SocioEconomic Challenges, 1(1), 54-59.

Schoukens, P. (2016). The EU monitoring of social security systems: in search of the hidden European social model. Tilburg: Tilburg University.

Pozo, S. (2018). The Human and Economic Implications of 21st Century Immigration Policy. Kalamazoo: W.E. Upjohn Institute.

Young, A., \& Tackett, M. (2018). Globalization and the decline in labor shares: Exploring the relationship beyond trade and financial flows. European Journal of Political Economy, 52, 18-35.

Mandelman, F. S. (2016). Labor market polarization and international macroeconomic dynamics. Journal of Monetary Economics, 79, 1-16.

Naiditch, C., Tomini, A., \& Lakhdar, C. (2015). Remittances and incentive to migrate: An epidemic approach of migration. International Economics, 142, 118-135.

Chiswick, B., \& Miller P. (2014). Handbook of the Economics of International Migration. Volume 1B. Washington: George Washington University.

Han, K. (2013). Saving public pensions: Labor migration effects on pension systems in European countries. The Social Science Journal, 50(2), 152-161.

Fisher, M. (2013). Migration: A World History. Oxford: Oxford University Press.

Klein, P., \& Ventura, G. (2009). Productivity differences and the dynamic effects of labor movements. Journal of Monetary Economics, 56(8), 1059-1073.

Mueller, C. (1982). The Economics of Labor Migration. Washington: Academic Press.

Public Union "Economic Discussion Club" (2019). Analytics. Retrieved from: http://edclub.com.ua/analityka (in Ukrainian)

State Statistics Service of Ukraine (2019). Official web-site. Retrieved from: http://www.ukrstat.gov.ua (in Ukrainian)

Eurostat (2018). Population change - Demographic balance and crude rates at national level. Retrieved from: http://appsso.eurostat.ec.europa.eu/nui/show.do?dataset=demo_gind

National Bank of Ukraine (2019). Official web-site. Retrieved from: https://www.bank.gov.ua (in Ukrainian)

Human Development Reports (2018). Statistical Update. Retrieved from: http://hdr.undp.org/en/2018-update

Centre for Economic Strategy (2019). Skilky ukrayintsiv poyikhalo za kordon i shcho derzhavi $z$ tsym robyty [Migration: how many Ukrainians went abroad and what to do with the state]. Retrieved from: http://preview.mailerlite.com/k5j3z7/877502734847182728/u3r0 (in Ukrainian) 